Bioelectrochemistry and Bioenergetics, 28 (1992) 443-450

A section of J. Electroanal. Chem., and constituting Vol. 343 (1992)

Elsevier Sequoia S.A., Lausanne

JEC BB 01536

\title{
Electrochemistry of omeprazole, active metabolites and a bound enzyme model. Possible involvement of electron transfer in anti-ulcer action
}

\author{
James R. Ames ${ }^{a, \star}$ and Peter Kovacic ${ }^{b, \star}$ \\ ${ }^{\prime}$ Department of Chemistry, The University of Michigan-Flint, Flint MI 48502 (USA) \\ ${ }^{b}$ Department of Chemistry, University of Wisconsin-Milwaukee, Milwaukee, WI 53201 (USA)
}

(Received 16 January 1992)

\begin{abstract}
Electrochemical studies were performed with omeprazole, active metabolites and a bound enzyme model. The active metabolites, cyclic sulfenamide and sulfur radical entities, exhibited reduction potentials of $-0.3 \mathrm{~V}$ and $-0.2 \mathrm{~V}$ respectively. The value for the bound enzyme model was $-0.7 \mathrm{~V}$ and that for omeprazole was $>-1.4 \mathrm{~V}$. The results lend credence to the hypothesis that electron transfer comprises part of the mode of action in addition to $\left(\mathrm{H}^{+} / \mathrm{K}^{+}\right)$ATPase inhibition.
\end{abstract}

\section{INTRODUCTION}

Benzimidazole sulfoxides, such as omeprazole 1 (Fig. 1) are potent anti-ulcer agents [1-6]. The proposed mode of action involves inhibition of gastric acid secretion into the lumen of the stomach by blockage of $\left(\mathrm{H}^{+} / \mathrm{K}^{+}\right)$ATPase (proton pump) of the parietal cell. Omeprazole itself is not the actual inhibitor of the enzyme, but must be transformed into an "active principle" within the cell [1,3,5]. Two of the most likely active substances are the thiophilic cyclic sulfenamide 2 [1-5], and the radical 6 formed by loss of water and rearrangement [6]. Both materials are thought to inactivate the ATPase by binding via mercapto groups [5,6], e.g. formation of 3a from 2 . We suggest that a prior or subsequent mechanism may entail electron-transfer (ET) processes (redox chemistry) [7] which might alter enzymatic reactions including proton pumping. The proposed active metabo-

\footnotetext{
ॠ To whom correspondence should be addressed.
} 
<smiles>COc1ccc2nc(S(=O)Cc3ncc(C)c(OC)c3C)[nH]c2c1</smiles>

1

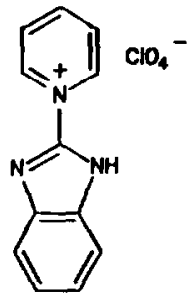

4

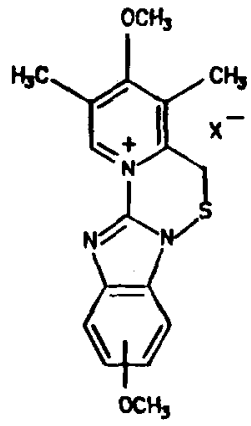

2

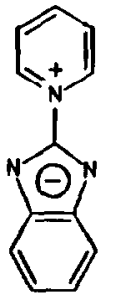

5<smiles>COc1ccc2nc(-[n+]3cc(C)c(OC)c(C)c3C[SeH])[nH]c2c1</smiles>

o) $R$ - onxyme rosidue

b) $\mathrm{R}=\mathrm{CH}_{2} \mathrm{CH}_{2} \mathrm{OH}$<smiles>Sc1c2ccccn2c2nc3ccccc3n12</smiles>

Fig. 1. Structures of the compounds studied.

lites contain potential ET functionalities (conjugated iminium [8-11] or odd electron species [12]). We have previously proposed a similar mode of action for the anticancer agents methotrexate and difluoromethylornithine [8] and for $\beta$ lactam antibiotics [9-11]. Conjugated iminium ions may play a role in proton pumping in the vision process via photo-induced intramolecular ET [13,14]. Apparently, the need for transformations such as $\mathbf{1} \rightarrow \mathbf{2} \rightarrow \mathbf{3 a}$ is not essential in vivo. Thus, Fischli et al. [15] reported that salts structurally related to 3 a protect rats against gastric ulceration. Quinolinium salts also inhibit $\left(\mathrm{H}^{+} / \mathrm{K}^{+}\right)$ATPase [16]. However, the need for binding to the enzyme may still be required.

The aim of the current study was to investigate the electrochemical properties of omeprazole, and particularly the active agents, based on the hypothesis of catalytic ET participation in the mode of action.

\section{EXPERIMENTAI}

Omeprazole 1 was a gift from AB Hässle, Sweden. Timoprazole was prepared as reported [17] $\left(\mathrm{MP}, 148-150^{\circ} \mathrm{C}\right.$; literature $\left.\mathrm{MP}, 150-154^{\circ} \mathrm{C}\right)$. Salt $2\left(\mathrm{X}=\mathrm{BF}_{4}\right)$ was synthesized by the method of Figala et al. [1] (MP, $151^{\circ} \mathrm{C}$ dec.; reported MP, $150^{\circ} \mathrm{C}$ dec. [4]). The analogous ion generated from timoprazole could not be isolated; 
Senn-Bilfinger et al. [4] have reported similar failure. The enzyme bound model 3b was prepared by literature methods [18]. Reaction of 2-chlorobenzimidazole with pyridine yielded 4 , isolated as the perchlorate $\left(\mathrm{MP}, 230-232^{\circ} \mathrm{C}\right.$; literature MP, $232-233^{\circ} \mathrm{C}$ [19]). The ylide 5, prepared from 4 [19], gave an MP of $256-257^{\circ} \mathrm{C}$ dec. (reported MP, about $260^{\circ} \mathrm{C}$ dec). Radical species 6 resulted from the decomposition of timoprazole in $0.1 \mathrm{M} \mathrm{HCl}$ at room temperature [6]. The supporting electrolyte, tetraethylammonium perchlorate (TEAP) (G.F. Smith Chemical Co.), was used without further purification. Dimethylformamide (DMF) and acetonitrile, both HPLC grade (Aldrich Chemical Co.), were used as obtained. Aqueous buffers, $\mathrm{pH} 5.1$ (potassium hydrogen phthalate (KHP)) and $\mathrm{pH} 7.0$ (phosphate), were prepared by standard methods [20].

Cyclic voltammetry and normal pulse polarography were performed in the dark using a Princeton Applied Research Corporation (PARC) model 264A polarographic analyzer connected to a PARC model 303A SMDE as previously reported [21].

\section{RESULTS AND DISCUSSION}

The reduction potential (more negative than $-1.4 \mathrm{~V}$ ) (Table 1) of omeprazole would not be amenable to participation of ET reactions in vivo. However, since 1 is a prodrug [1], the value has little significance. Benzimidazole sulfoxides incapable of forming ions of type $\mathbf{2}$ show no anti-ulcer activity [1]. An irreversible reduction of $-0.36 \mathrm{~V}$ was observed for 2 (Table 1) in acetonitrile [5]. The wave had an $E_{\mathrm{pp} / 2}$ of $100 \mathrm{mV}$; the value is normally about $60 \mathrm{mV}$ for a single electron transfer [ref. 23 , p. 213). Perhaps the width reflects the presence of two regio-isomers, $10-\mathrm{OCH}_{3}$

\section{TABLE 1}

Reduction potentials of omeprazole and conjugated pyridinium ions ${ }^{\text {a }}$

\begin{tabular}{|c|c|c|c|c|c|}
\hline \multirow[t]{2}{*}{ Compound } & \multicolumn{2}{|c|}{$\mathrm{CH}_{3} \mathrm{CN}$ solvent } & \multicolumn{2}{|c|}{ DMF solvent } & \multirow{2}{*}{$\frac{\mathrm{H}_{2} \mathrm{O} \text { solvent }}{E_{\mathrm{p}} / \mathrm{V}}$} \\
\hline & $E_{\mathrm{p}} / \mathrm{V}$ & $E_{\mathrm{pp} / 2} / \mathrm{mV}$ & $E_{\mathrm{p}} / \mathrm{V}$ & $E_{\mathrm{pp} / 2} / \mathrm{mV}$ & \\
\hline 1 & - & - & $>-1.4$ & - & - \\
\hline $2^{b}$ & -0.36 & 100 & -0.30 & 105 & - \\
\hline $3^{b}$ & $-0.75^{c}$ & 160 & -0.74 & 150 & - \\
\hline $4^{b}$ & -0.49 & 70 & -0.48 & 60 & $-0.65^{\mathrm{d}},-0.71^{\mathrm{e}}$ \\
\hline 5 & -1.02 & 75 & -0.96 & 50 & $-0.72^{f}$ \\
\hline
\end{tabular}

\footnotetext{
a Substrate concentration $0.5 \mathrm{mM}$; [TEAP] $=0.1 \mathrm{M}$; potentials measured versus the standard calomel electrode (SCE) adjusted to the standard hydrogen electrode (SHE); scan rate, $0.1 \mathrm{~V} / \mathrm{s}$.

${ }^{b}$ Electrochemistry in $0.1 \mathrm{M} \mathrm{HCl}$ was accompanied by severe adsorption at the $\mathrm{Hg}$ electrode, similar to aqueous omeprazole [22].

c Single determination.

${ }^{\mathrm{d}} \mathrm{pH} 5.1$, adsorption peak at $-0.40 \mathrm{~V}$.

e $\mathrm{pH} 7.0$, adsorption peak at $-0.47 \mathrm{~V}$.

${ }^{\mathrm{f}} \mathrm{pH} 7.0$, adsorption peak at $-0.49 \mathrm{~V}$.
} 
and $9-\mathrm{OCH}_{3}$, which form in a $2: 1$ ratio [1,4]. Calculation of simple Hückel molecular orbitals [24] indicate that the major isomer has a slightly lower lying lowest unoccupied molecular orbital (LUMO) which may result in somewhat different reduction potentials for the two isomers. The first half-wave potentials for related aza-heteroaromatic compounds correlated well with the energies of the lowest vacant molecular orbitals calculated by Hückel methods [25]. In DMF an $E_{\mathrm{p}}$ of $-0.30 \mathrm{~V}$ was obtained with an $E_{\mathrm{pp} / 2}$ value of $105 \mathrm{mV}$. The material adsorbed strongly at the mercury electrode in $\mathrm{pH} 5.1$ buffer. No further studies were performed.

A model of the enzyme bound inhibitor is $\mathbf{3 b}[26,27]$. The presence of pyridinium in the enzyme inhibitor complex is thought to be important [27]. Under our non-aqueous conditions, $3 \mathrm{~b}$ reduced about $400 \mathrm{mV}$ more negative than the cyclic sulfenamide with a peak width of $150 \mathrm{mV}$. The difference is probably due mainly to the decrease in coplanarity of the two heteroaromatic rings; salt 3 is relatively free to rotate about the $\mathrm{C}-\mathrm{N}$ bond, whereas the additional bridge in 2 enforces a more coplanar arrangement [4,28]. There is also a shift in the UV absorption maxima toward shorter wavelengths upon formation of $\mathbf{3 b}$ [29], indicating decreased $\pi$ overlap. Reports of other bridged biaryl systems reveal similar influences of coplanarity on reduction potential and UV spectra [30-32]. The reaction is probably due to the reduction of the pyridinium ring and not the disulfide linkage since diphenyl disulfide did not exhibit electron uptake prior to $-1.3 \mathrm{~V}$ in DMF. The reduction potential of 3 is slightly more negative than the value of -0.6 $\mathrm{V}$ which is believed to be the limit for in vivo functioning [33]. However, if binding to enzyme induces a more coplanar arrangement in 3 , then $E_{1 / 2}$ would become more positive.

The effect of substituents is shown by comparison of salts $3 b$ and 4 . The potential of the inhibited enzyme model should be about $240 \mathrm{mV}$ more negative than for 4; the alkyl group makes reduction more difficult by up to $80 \mathrm{mV}$ [34], and incorporation of a methoxy substituent in position 4 of the pyridine ring in the $N$-phenylpyridinium ion decreases the reduction value by $0.03 \mathrm{~V}$ [35]. Table 1 reveals a difference of $0.26 \mathrm{~V}$, indicating similar rotation about the $\mathrm{C}-\mathrm{N}$ bond in both salts. Related ions of the $N$-styrylpyridinium type reduce in the range from -0.6 to $-0.7 \mathrm{~V}$ [21]. In the present study, increased conjugation favors greater ease of electron uptake.

In order to gain a better understanding of the reduction process, normal pulse polarography was performed on ion $4\left(E_{1 / 2}=-0.44 \mathrm{~V}\right)$ and the results are given in Table 2. Comparison of limiting currents for $4(2.7 \mu \mathrm{A})$ with those for the $N$-benzylpyridinium ion $(3.6 \mu \mathrm{A})$, a substance known to be reduced by one electron [36], indicate that the same number of electrons is being transferred. A one-electron transfer was also indicated by a value of $67 \mathrm{mV}$ for a plot of $E$ versus $\log \left[\left(I_{\mathrm{d}}-I\right) / I\right]$; the theoretical value is $59 \mathrm{mV}$ (ref. $23, \mathrm{p} .136$ ).

The ylide of 2 may be generated by nucleophilic attack on the sulfur of cyclic sulfenamide with formation of benzimidazolide [1]. The expected reduction value for the ylide should be even more negative than that of model 5 ( $E_{\mathrm{p}} \approx-1 \mathrm{~V}$ 
TABLE 2

Normal pulse polarography of 4 and 5 a

\begin{tabular}{llll}
\hline Compound & $E_{1 / 2} / \mathrm{V}$ & $I_{\mathrm{d}} / \mu \mathrm{A}$ & $E_{3 / 4}-E_{1 / 4}$ \\
\hline 4 & -0.44 & 2.7 & 57 \\
5 & -0.94 & 4.6 & 55 \\
\hline
\end{tabular}

a Substrate concentration $0.5 \mathrm{mM}$; [TEAP] $=0.1 \mathrm{M}$; DMF; potentials measured versus SCE adjusted to SHE.

${ }^{\mathrm{b}}$ Limiting currents for $N$-benzyl and $N$-methylpyridinium ions: $3.6 \mu \mathrm{A}$ and $4.5 \mu \mathrm{A}$ respectively.

(Table 1)) because of substituent effects (cf. $3 \mathbf{b}$ and 4). Ylide 5 exhibited a drawn-out anodic peak between zero and $+0.2 \mathrm{~V}$ in DMF. $E_{\mathrm{p}}$ for this anodic process was $+0.12 \mathrm{~V}$, similar to that for the 1-methylpyridinium ion [36]. These voltammetric features have been attributed to one-electron reduction to the pyridinyl radical, followed by rapid dimerization to the corresponding tetrahydropyridine moiety and oxidation of the dimeric species back to the original ion.

Pulse polarography was performed on 5 in DMF; an $E_{1 / 2}$ of $-0.94 \mathrm{~V}$ was observed (Table 2). The limiting current was $4.6 \mu \mathrm{A}$; the $N$-methylpyridinium ion gave an $I_{\mathrm{d}}$ of $4.5 \mu \mathrm{A}$. A value of $55 \mathrm{mV}$ was obtained for $E_{3 / 4}-E_{1 / 4}$.

Cyclic voltammetry in aqueous buffer solutions (Table 1) of $\mathbf{4}$ generated diffusion-controlled reduction peaks at $-0.71 \mathrm{~V}$ at $\mathrm{pH} 7.0$ and at $-0.65 \mathrm{~V}$ at $\mathrm{pH} 5.1$ with absorption peaks at -0.47 and $-0.40 \mathrm{~V}$ respectively. Examination of 5 at $\mathrm{pH}$ 7.0 resulted in a voltammogram almost indistinguishable from that of 4 . It is possible that 4 is generated from 5 under these conditions. A salt, e.g. 4, is formed from the ylide in aqueous acid [19].

The second active principle that may be involved in ET is the radical 6 . The results of our electrochemical studies are given in Table 3; all processes were reversible. In DMF 6 reduced at $-0.19 \mathrm{~V}$. There was a slight increase in the separation of peaks as the scan rate increased, the average being that for a one-electron transfer (ref. 23, p. 213), with the ratio of the anodic to the cathodic peak currents equal to unity. Thus the reaction is chemically reversible, i.e. the radical is regenerated as the potential is reversed. A difference of $80 \mathrm{mV}$ in $E_{1 / 2}$ was observed as the solvent was changed to acetonitrile, similar to that found for 2 .

Another electrochemical possibility for 6 is oxidation, which occurred at $0.54 \mathrm{~V}$ in both solvent systems. The separation of peaks is close to that for a one-electron process. However, as the scan rate decreased the ratio of the currents deviated substantially from unity, indicating that the cation is unstable and undergoes a chemical reaction subsequent to oxidation. The relationship of oxidation potential magnitude to feasibility of in vivo operation is discussed elsewhere [12].

Free radicals appear to be associated with the pathogenesis of gastric ulcers [37,38]. Radical scavengers such as $\beta$-carotene provide cytoprotection [38]. Perhaps the bound drug 3a, 2 or the radical 6 may act as an electron sink in the protection mechanism, thus inhibiting the formation of harmful radicals. 
TABLE 3

Electrochemistry of $6^{\mathrm{a}}$

\begin{tabular}{lcccll}
\hline Solvent & $\begin{array}{l}\text { Scan } \\
\text { rate } / \mathrm{mV} \mathrm{s}^{-1}\end{array}$ & $E_{\mathrm{p}} / \mathrm{V}$ & $E_{1 / 2} / \mathrm{V}$ & $E_{\mathrm{pp} / 2} / \mathrm{mV}$ & $I_{\mathrm{pa}} / I_{\mathrm{pc}}$ \\
\hline $\mathrm{DMF}^{\mathrm{b}}$ & 20 & -0.21 & -0.19 & 50 & 0.97 \\
& 50 & -0.21 & -0.19 & 57 & 1.03 \\
& 100 & -0.21 & -0.19 & 63 & 1.05 \\
& 200 & -0.22 & -0.19 & 72 & 1.1 \\
$\mathrm{CH}_{3} \mathrm{CN}^{\mathrm{b}}$ & 20 & -0.30 & -0.27 & 55 & 0.74 \\
& 50 & -0.30 & -0.27 & 55 & 1.03 \\
& 100 & -0.30 & -0.27 & 60 & 1.03 \\
& 200 & -0.31 & -0.27 & 75 & 1.1 \\
$\mathrm{DMF}^{\mathrm{c}}$ & 50 & 0.57 & 0.54 & 70 & 1.92 \\
& 100 & 0.58 & 0.54 & 70 & 1.78 \\
& 200 & 0.59 & 0.54 & 80 & 1.47 \\
$\mathrm{CH}_{3} \mathrm{CN}^{\mathrm{c}}$ & 50 & 0.56 & 0.54 & 50 & 1.13 \\
& 100 & 0.56 & 0.54 & 50 & 1.06 \\
& 200 & 0.56 & 0.54 & 50 & 1.02 \\
\hline
\end{tabular}

$\bar{a}[6]=0.5 \mathrm{mM} ;[$ TEAP $]=0.1 \mathrm{M} ;$ scan rate, $100 \mathrm{mV} / \mathrm{s} ;$ potentials measured versus $\mathrm{SCE}$ adjusted to SHE.

b Reduction process, $E_{\mathrm{pc}}$ values.

' Oxidation process, $E_{\mathrm{pa}}$ values.

In vitro studies with omeprazole and its analogs indicate that the bound drug can be displaced from the enzyme by the addition of thiols, which partially reactivated the enzyme $[1,39]$. According to our theory, removal of the electron carrier, i.e. the conjugated pyridinium ion, from the enzyme would eliminate participation of ET at the binding site. The cationic nature of $\mathbf{3}$ restricts membrane permeability, preventing the active inhibitor from entering the cell cytosol where it could result in non-specific inhibition [40]. Omeprazole has also been shown to interact with the mixed function oxidase system in vitro and in vivo [41].

Hence omeprazole metabolites can be regarded as proton-channel blockers [42]. If ET is involved, then similarity exists to calcium-channel antagonists [43] and benzodiazepines [44,45], for which ET mechanisms have been proposed to account in part for the influence on ion channels.

\section{OTHER CONSIDERATIONS}

If the hypothetical framework is correct, then other anti-ulcer drugs might also function in a similar manner. An attractive possibility is the metallatrane category [46]. The anti-ulcer effect appears to be mediated by the anti-oxidant activity. Nitrofurans [47] and $\mathrm{Cu}(\mathrm{II})$ complexes [48], which are known ET agents [7,49], also display anti-ulcer properties. SCH 28080 [50], which is readily protonated, would 
be transformed in the gastric region to a highly conjugated pyrrolopyridinium moiety that might well be capable of involvement in ET.

We have previously discussed the possible effects of in vivo binding on reduction potential and reversibility [51]. The ET approach has also been applied to various drugs, including fungicidal [52], anthelmintic [49] and antimycobacterial [7] compounds. References to other xenobiotics studied (carcinogens, anticancer agents, amebicides, antimalarials and central nervous system affecters) are given elsewhere [49].

\section{ACKNOWLEDGMENT}

We thank AB Hässle for a sample of omeprazole.

\section{REFERENCES}

1 V. Figala, K. Klemm, B. Kohl., U. Krüger, G. Rainer, H. Schaefer, J. Senn-Bilfinger and E. Sturm, Chem. Commun., (1986) 125.

2 W.A. Simon, D.J. Keeling, S.M. Laing, C. Fallowfield and A.G. Taylor, Biochem. Pharmacol., 39 (1990) 1799.

3 M. Morii, H. Takata, H. Fujisaki and N. Takeguchi, Biochem. Pharmacol., 39 (1990) 661.

4 J. Senn-Bilfinger, U. Krüger, E. Sturm, V. Figala, K. Klemm, B. Kohl, G. Rainer, H. Schaefer, T.J. Blake, D.W. Darkin, R.J. Ife, C.A. Leach, R.C. Mitchell, E.S. Pepper, C.J. Salter, N.J. Viney, G. Huttner and L. Zsolnai, J. Org. Chem., 52 (1987) 4582.

5 A. Brändström, P. Lindberg, N.-A. Bergman, T. Alminger, K. Ankner, U. Junggren, B. Lamm, P. Nordberg, M. Erickson, I. Grundevik, I. Hagin, K.-J. Hoffmann, S. Johansson, S. Larsson, I. Löfberg, K. Ohlson, B. Persson, I. Skånberg and L. Tekenbergs-Hjelte, Acta Chem. Scand., 43 (1989) 536.

6 G. Rackur, M. Bickel, H.-W. Fehlhaber, A. Herling, V. Hitzel, H.-J. Lang, M. Rösner and R. Weyer, Biochem. Biophys. Res. Commun., 128 (1985) 477.

7 P. Kovacic, J.R. Ames and M.D. Ryan, Bioelectrochem. Bioenerg., 21 (1989) 269.

8 P. Kovacic, J.R. Ames, E.C. Taylor and M.D. Ryan, J. Pharm. Sci., 77 (1988) 999.

9 P. Kovacic, M. Jawdosiuk, J.R. Ames and M.D. Ryan, Bioorg. Chem., 15 (1987) 423.

10 P. Kovacic, J.R. Ames and M.D. Ryan, Bioorg. Chem., 16 (1988) 149.

11 P. Kovacic, J.R. Ames and M.D. Ryan, Free Rad. Res. Commun., 7 (1989) 19.

12 P. Kovacic, J.R. Ames, M. Jawdosiuk and M.D. Ryan, in G. Dryhurst and K. Niki (Eds.), Redox Chemistry and Interfacial Behavior of Biological Molecules, Plenum Press, New York, 1988, p. 323.

13 L. Salem, Acc. Chem. Res., 12 (1979) 87.

14 A.D. Kaulen, L.A. Drachev and V.V. Zorina, Biochem. Biophys. Acta, 1018 (1990) 103.

15 A. Fischli, A. Krasso and A. Szente, European Patent Application EP 30624; Chem. Abstr., 111 (1989) 194761.

16 C. Santini, US Patent 4859679; Chem. Abstr., 112 (1990) 55914.

17 P.B. Berntsson, S.A.I. Carlsson, L.E. Garberg, U.K. Junggren, S.E. Sjostrand and G.W. von Wittken Sundell, US Patent 4045563, 1977.

18 A. Brändström, P. Lindberg, N.-A. Bergman, I. Grundevik, L. Tekenbergs-Hjelte and K. Ohlson, Acta Chem. Scand., 43 (1989) 595.

19 G.V. Boyd, Tetrahedron Lett., (1966) 3369.

20 R.C. Weast (Ed.), CRC Handbook of Chemistry and Physics (64th edn.), CRC Press, Boca Raton, FL, 1983, p. D150.

21 J.R. Ames, J. Pharm. Sci., 80 (1991) 293. 
22 B.-L. Johansson and S. Wendsjo, J. Electroanal. Chem., 235 (1987) 343.

23 A.J. Bard and L.R. Faulkner, Electrochemical Methods, Wiley, New York, 1980.

24 HMO: A Graphics-Based Huckel Molecular Orbital Calculator, Trinity Software, Campton, NH.

25 S. Kato, J. Nakaya and E. Imoto, Rev. Polarogr., 17 (1971) 1.

26 A. Brändström, P. Lindberg, N.-A. Bergman, L. Tekenbergs-Hjelte and K. Ohlson, Acta Chem. Scand., 43 (1989) 577.

27 P. Lindberg, P. Nordberg, T. Alminger, A. Brändström and B. Wallmark, J. Med. Chem., 29 (1986) 1327.

28 E. Sturm, U. Krüger, J. Senn-Bilfinger, V. Figala, K. Klemm, B. Kohl, G. Rainer, H. Schaefer, T.J. Blake, D.W. Darkin, R.J. Ife, C.A. Leach, R.C. Mitchell, E.S. Pepper, C.J. Salter, N.J. Viney, G. Huttner and L. Zsolnai, J. Org. Chem., 52 (1987) 4573.

29 W.B. Im, J.C. Sih, D.P. Blakeman and J.P. McGrath, J. Biol. Chem., 260 (1985) 4591.

30 R.P. Thummel, V. Goulle and B.J. Chen, J. Org. Chem., 54 (1989) 3057.

31 J.R. Ames, unpublished results.

32 P. Kovacic, W.D. Edwards and G. Ming, Free Rad. Res. Commun., 14 (1991) 25.

33 D.M. Frank, P.K. Arora, J.L. Blumer and L.M. Sayre, Biochem. Biophys. Res. Commun., 147 (1987) 1095.

34 A. Albert, Selective Toxicity (7th edn.), Chapman and Hall, New York, 1985, p. 51.

35 P. Zuman, Substituent Effects in Organic Polarography, Plenum Press, New York, 1967, p. 148.

36 R. Raghavan and R.T. Iwamoto, J. Electroanal. Chem., 92 (1978) 101.

37 M. Inoue, M. Hirota, Y. Ando, I. Ebashi, N. Watanabe, M. Akagi and Y. Morino, Excerpta Med Int. Congr. Ser., 767 (1988) 93; Chem. Abstr., 110 (1989) 128401.

38 A. Vincze, M. Garamszegi, T. Javor, G. Suto, A. Tigyi, Gy. Toth, T. Zsoldos and Gy. Mozsik, Acta Physiol. Hung., 73 (1989) 351; Chem. Abstr., 112 (1990) 69749.

39 H. Nagaya, H. Satoh, K. Kubo and Y. Maki, J. Pharmacol. Exp. Therapeut., 248 (1989) 799.

40 G. Saccomani and S.J. Hersey, Drug Metab. Drug Interact., 7 (1989) 161.

41 R.J. Chenery, A. Ayrton, H.G. Oldham, S.J. Norman and P. Standring, Biochem. Pharm., 37 (1988) 1407.

42 P. Lindberg, A. Brändström, B. Wallmark, H. Mattson, L. Rikner and K-J Hoffman, Med. Res. Rev., 10 (1990) 1.

43 P. Kovacic, W.D. Edwards, N.R. Natalc, R. Sridhar and P.F. Kiser, Chem.-Biol. Interact., 75 (1990) 61.

44 P.W. Crawford, P. Kovacic, N.W. Gilman and M.D. Ryan, Bioelectrochem. Bioenerg., 16 (1986) 407.

45 H.O. Villar, E.T. Uyeno, L. Toll, W. Polgar, M.F. Davies and G.H. Loew, Mol. Pharm., 36 (1989) 589.

46 I.G. Kuznetsov, M.M. Rasulov, Yu.V. Pisarskii, S.K. Suslova, M.V. Velikaya and M.G. Voronkov, Khim.Farm. Zh., 24 (11) (1990) 10.

47 B.H. Ali, Pharmacology, 42 (1991) 49.

48 D. Frechilla, B. Lasheros, M. Ucelay, E. Parrondo, G. Craciunescu and E. Cenarruzabeitia, Arzneim. Forsch., 41 (1991) 247.

49 P. Kovacic, J.R. Ames, D.L. Rector, M. Jawdosiuk and M.D. Ryan, Free Rad. Biol. Med., 6 (1989) 131.

50 C.K. Scott and E. Sundell, Eur. J. Pharmacol., 112 (1985) 268.

51 J.R. Ames, S. Brandänge, B. Rodriguez, N. Castagnoli, Jr., M.D. Ryan and P. Kovacic, Bioorg. Chem., 14 (1986) 228.

52 P. Kovacic, P.F. Kiser and B.F. Feinberg, Pharm. Res., 7 (1990) 283. 